\title{
European “Judicial Monologue” of the Czech Constitutional Court - a Critical Review of its approach to the Preliminary Ruling Procedure
}

\author{
David Sehnálek
}

Faculty of Law, Masaryk University, Czech Republic

\author{
david.sehnalek@law.muni.cz
}

\section{Václav Stehlík}

Faculty of Law, Palacký University Olomouc, Czech Republic vaclav.stehlik@upol.cz

SEHNÁLEK, David; STEHLÍK, Václav. European "Judicial Monologue" of the Czech Constitutional Court - a Critical Review of its approach to the Preliminary Ruling Procedure. International and Comparative Law Review, 2019, vol. 19, no. 2, pp. 181-199. DOI: 10.2478/iclr-2019-0020.

\begin{abstract}
Summary: The paper analyses the use of the preliminary ruling procedure by the Czech Constitutional Court and the attitude of this court towards the EU law. The approach of the Constitutional Court to the judicial dialog is also compared with some other European constitutional courts mainly with those who have a similar role in national judiciary or with those who were able to effectively take an advantage of the preliminary ruling procedure. The paper demonstrates that the Czech Constitutional Court took the position that seems to be unsustainable from a long time perspective as the reality of the current development favours the spirit of cooperation among European highest courts.
\end{abstract}

Keywords: Czech courts, Czech Constitutional Court, Court of Justice of the European Union, preliminary ruling procedure, judicial dialog, European constitutionalism.

\section{Introduction}

The Czech Republic has been a Member State of the European Union for 15 years now. This is long enough in order to be able to assess the approach of the Czech Constitutional Court to the Court of Justice of the EU (further referred as "Court of Justice") via the preliminary ruling procedure under art. 267 TFEU. It is also a sufficient time in which the Constitutional Court could develop its own doctrine of the relation between the EU law and the Czech legal order. 
According to Zemánek, ${ }^{1}$ the Constitutional Court had a choice among three strategies how to approach the EU law and, subsequently, also the preliminary ruling procedure. It could:

1. approach the EU law in the same way as the Court of Justice does and consider the EU law as an autonomous legal order which is fully independent on Czech law;

2. consider the EU law to be a part of the Czech constitutional order;

3. understand both the EU law and the Czech law as forming a new system composed of two separate systems of law in which they interact with a potential of conflicts. The role of the Constitutional Court is to resolve them, but only if such conflicts would threaten the functionality of this system. ${ }^{2}$

Out of the three options only the first one is fully compatible with the EU law and with the jurisprudence of the Court of Justice ${ }^{3}$ which implies the existence of so called European constitutional pluralism in the EU. ${ }^{4}$ Second and third options can be perceived as rather conservative and based on traditional Kelsen's model of law as a uniform hierarchic system. ${ }^{5}$ Within such an approach, the EU law is more or less subordinated to the national law. The practical result is that whereas under the first option the Constitutional Court may be more willing to cooperate with the Court of Justice and participate on a judicial dialogue through the preliminary ruling procedure, under the second or third option its willingness to join the judicial dialogue would be lowered because of a risk of a conflict between the two courts as they approach to the EU law and its interpretation and application might be different.

The aim of this article ${ }^{6}$ is to analyse relevant decisions of the Constitutional Court dealing with its approach to the EU law and to the preliminary ruling pro-

1 ZEMÁNEK, Jiří. České ústavní soudnictví v evropském ústavním prostoru in Vlastimil Göttinger (ed.) Book of proceedings from international conference EUROPEAN CONSTITUTIONALISM IN THE CONTEXT OF JUDICIAL DIALOGUE. Brno: Ústavní soud, 2016, p. 89.

2 Ibidem, p. 89-90.

3 C-26/62 NV Algemene Transport - en Expeditie Onderneming van Gend \& Loos v Netherlands Inland Revenue Administration, ECLI:EU:C:1963:1 and C-6/64 Flaminio Costa v E.N.E.L., ECLI:EU:C:1964:66.

4 See also HAMULÁK, Ondrej, Lessons from the "Constitutional Mythology" or How to Reconcile the Concepts of State Sovereignty with European Integration. DANUBE: Law and Economics Review, vol. 6, no. 2, pp. 75-90.

5 SCHEU, Harald, Christian. Koncepce komunitárního práva v praxi Evropského soudního dvora a v právní teorii. Mezinárodní vztahy, 2002, no. 1, p. 17.

6 The article extends a previously finished paper which focused generally on the evaluation of the use of preliminary ruling procedure by all Czech courts since the beginning of the Czech membership to the EU, therefore, some parts of this paper are reitarated and substantially extended, for more see STEHLÍK, V., SEHNÁLEK, David, The Use of the Preliminary Ruling Procedure by Czech Courts: Historical Retrospective and Beyond, 
cedure in particular. The article will be divided into six chapters of which the first will be introductory and the last will contain conclusions and closing remarks. The second chapter of this article will shortly address the approach of European constitutional courts towards the preliminary procedure. The third chapter will focus primarily on the position of the Czech Constitutional Court and on the arguments this court uses in order to avoid the duty to initiate the preliminary ruling procedure. The fourth part will deal with the consequences the approach of the Czech Constitutional Court has on the judicial dialog with the Court of Justice. The fifth chapter will explain that the Constitutional Court may not be willing to initiate the preliminary ruling procedure itself, but it is ready to promote it at the level of Czech ordinary courts even via the constitutional law.

On the other hand, the article will not deal with preliminary rulings initiated by common Czech courts including the supreme courts. ${ }^{7}$ The analysis will follow the timeline within which the relevant decisions were taken.

\section{General Remarks on Constitutional Courts and Preliminary Ruling Procedure}

While ordinary courts, including the supreme ones, initiate the preliminary ruling procedure or have a clear obligation to do it, the constitutional judiciary is far more complicated in this regard. Some constitutional courts actively cooperate with the Court of Justice, ${ }^{8}$ others are more hesitant in this regard. Some of the constitutional courts denied their formal role to initiate the ruling in a long time perspective, but they have changed their approach in recent years. ${ }^{9}$ For example, the German Federal Constitutional Court has lodged 3 preliminary ruling requests, the same stands for the Italian Constitutional Court. The French, Spanish, Polish Constitutional Courts have lodged one request each. ${ }^{10}$

accepted by Baltic Journal of European Studies, no. 4, 2019.

7 For an analysis on use of the preliminary ruling procedure by ordinary courts see for example: STEHLÍK, Václav. Ohlédnutí se (nejen) za řízením o předběžné otázce v prvních 15 letech členství České republiky v Evropské unii In KYSELOVSKÁ, Tereza et al. (eds.) In varietate concordia: soubor vědeckých statí k poctě prof. Vladimíra Týče. Brno: Masaryk University, pp. 347-366.

8 For instance, the Belgian Cour constitutionnelle with its 38 references.

9 For a more detailed analysis see NAVRÁTILOVÁ, Markéta. The preliminary ruling before the constitutional courts, In TÝČ, Vladimír (ed.): International and European Dimension of Law Applied by Institutions of Member States, Brno: Masaryk University, 2008, p. 8. The analysis of the first preliminary ruling requests lodged by the French, Spanish or Italian Constitutional Courts see for example KUSTRA, Aleksandra. The first preliminary questions to the Court of Justice of the European Union referred by Italian Corte Costituzionale, Spanish Tribunal Constitucional, and French Conseil Constitutionnel. Comparative Law Review, Toruń: Faculty of Law, Mikulas Kopernik University, vol. 16, 2013, p. 159182.

10 The statistics is available in the annual report of Court of Justice activities: https://curia. europa.eu/jcms/jcms/Jo2_7000/cs/. 
One of the reasons for a greater reservation of the constitutional courts is the perception of the constitutional courts as guardians of constitutionality even vis$\grave{a}$-vis the EU law. The EU law may stand outside their decision-making framework if perceived from a traditional constitutional perspective. Moreover, the constitutional courts might have a fear that by initiating the preliminary ruling procedure, they would be obliged to conform (in a full extent) to the interpretation of the Court of Justice; even in relation to the fundamental principles and values which they should guard. ${ }^{11}$ The fear of the necessity to unconditionally subordinate to the conclusions of the Court of Justice is unjustified, though. ${ }^{12}$ For instance the preliminary ruling request can serve as the last resort chance for the Court of Justice - based on the compelling argumentation - to review the impact of the EU law on fundamental values rooted in the constitutional rules of the Member States and by doing so to avoid the disapplication of the EU legislation in the Member State concerned. This is apparent from recent German ${ }^{13}$ and Italian cases, the most important will be analyzed further in this article.

\section{Czech Constitutional Court and Preliminary Ruling Procedure}

The position of the Czech Constitutional Court is so far unequivocal in that it has not referred any preliminary ruling request yet. Its case-law regarding the question whether it is the court under art. 267 TFEU is rather blurred. Thus, it is not clear without any doubt whether this court is willing to enter into a judicial dialog with the Court of Justice or not. Its conclusions in its decisions dealing with the preliminary procedure proceedings, however, reveal much about its attitude towards this procedure as well as to the Court of Justice and the EU law in general. ${ }^{14}$

11 See also HAMULÁK, Ondrej; SULYOK, Márton, KISS, Lilla, Nóra. Measuring the 'EU'clidean Distance between EU Law and the Hungarian Constitutional Court - Focusing on the Position of the EU Charter of Fundamental Rights. Czech Yearbook of Public and Private International Law, 2019, vol. 10, pp. 130-150.

12 An example thereof could be also the decision of the Czech Constitutional Court in Holubec (Slovak pensions case). Judgement of the Constitutional Court, Pl. US 5/12 of 31 January 2012.

13 This was the case of the preliminary ruling request lodged by the German Federal Constitutional Court in case OMT BvR 2728/13 et al., which led the Court of Justice to the case Gauweiler and others, ECLI:EU:C:2015:400. See more in: HAMULÁK, Ondrej, KOPAL, David, KERIKMÄE, Tanel. Walking a Tightrope-Looking Back on Risky Position of German Federal Constitutional Court in OMT Preliminary Question. European Studies: the review of European law, economics and politics. Prague: Wolters Kluwer, vol. 3, 2016, p. 115-141; or GEORGIEV, Jiři. The Constitutional Review of the OMT Programme - The German Case. In: ŠIŠKOVÁ, Naděžda. The European Union - What is Next? Wolters Kluwer: Köln, 2018, p.165 et seq.

14 See further HAMULÁK, Ondrej. The Czech Constitutional Court and the Question of an Active Use of the Preliminary Ruling Procedure. In R. Somssich (ed.) Central and Eastern European Countries after and before the Accession, Volume 2. Budapest: ELTE, pp. 121-128. 
3.1 Case 'Cukerné kvóty': Argument by Specific Nature of Judicial Competences of the Constitutional Court

The first time where the Czech Constitutional Court expressed its opinion on the initiation of the preliminary ruling was the case Cukerné kvóty. ${ }^{15}$ There, the Constitutional Court admitted that some constitutional courts in other EU Member States did consider themselves to be a regular part of the judiciary (i.e. courts as such) and would refer questions for a preliminary ruling. However, it merely noted this fact and did not examine the legal arguments underpinning their conclusions. ${ }^{16}$ The Czech Constitutional Court also noted that the Italian Constitutional Court, for example, would not refer questions for a preliminary ruling and explained why: the Italian Constitutional Court did not consider itself to be a court within the meaning of Art. 267 TFEU and, moreover, Art. 267 TFEU could not be applied in certain types of procedures conducted by this court (e.g. the abstract control of legality - abstrakteNormenkontrolle).

There is one more issue worth mentioning with regard to the approach of the Czech Constitutional Court - while arguments for a certain (desired) conclusion are outlined, arguments supporting the opposite conclusion are not mentioned at all. Moreover, the argument used is ultimately unconvincing. The comparison with other countries' constitutional courts, insofar as it was tentatively outlined, is not consistent since the individual national constitutional courts may have different functions and serve different purposes. ${ }^{17}$ The scope of their powers varies, which means that any comparison attempted should not be limited to a generally defined task (delivering constitutional justice), but should focus on concrete functions of the courts that are being compared. Therefore, the question we should be asking is which of the constitutional courts refer questions for a preliminary ruling in identical or at least similar judicial procedures.

The conclusion the Czech Constitutional Court reached in case Cukerné kvóty reminds one of Pythia's ambiguous answers: "The Constitutional Court is aware of the delicate nature of finding the answer to the question of whether the Constitutional Court can be considered a court pursuant to Art. 234 of the EC Treaty, and if so, in which types of procedures, and reserves the possibility to arrive at a clear answer to this question in the future, i.e., refer the case in individual types of procedures to the ECJ (...)". Subsequently, the Constitutional Court notes that the problem is a matter with an obvious interpretation in the sense of the CILFIT decision. ${ }^{18}$ Therefore, while the Constitutional Court concluded in this proceeding that referring a question for a preliminary ruling might be legitimate,

15 Pl. ÚS 50/04 - Cukerné kvóty, ECLI:CZ:US:2006: Pl.ÚS.50.04.

16 For explanation of these reasons see for example BOBEK, Michal., KOMÁREK, Jan., PASSER, M., Jan, GILLIS, M. Předběžná otázka v komunitárním právu. Praha: LINDE Praha a.s., 2005, p. 72 and 73 .

17 Ibidem.

18 C-283/81. Srl CILFIT and Lanificio di Gavardo SpA v Ministry of Health. ECLI:EU:C:1982:335. 
especially in proceedings concerning abstract control of constitutionality, it ultimately did not do so and evaded the answer. The same thing happened in other proceedings.

3.2 Case 'Pfizer': First Comprehensive Analysis and the EU Law as Sub-constitutional Law Argument

An analysis of the obligation to refer a question for a preliminary ruling pursuant to Art. 267 TFEU, hitherto missing in the case law of the Constitutional Court, was conducted in case Pfizer. ${ }^{19}$ In this decision, the Czech Constitutional Court emphasised the function it served within the framework of Czech constitutional justice. It stressed that it was not a part of the system of ordinary courts that includes administrative, civil and criminal justice. In this conception, the reference framework consists solely in constitutionality, i.e., compliance with the normative and value categories of the Constitution. According to the Constitutional Court, a constitutional complaint, thus, cannot be understood as a type of ordinary or extraordinary remedy in the given case and, consequently, the Constitutional Court does not constitute another instance within the system of courts.

The Constitutional Court further concluded that "Community law is not part of the constitutional order and, therefore, the Constitutional Court is not competent to interpret it. Nevertheless, the Constitutional Court cannot entirely overlook the impact of Community law on the creation, application and interpretation of national law in the area of legal regulations whose creation, effect and purpose are directly linked to Community law (...) However, the two supreme courts are the ones within the system of ordinary courts that ensure the consistency of judicial decisions in the Czech Republic within the scope of their statutory competences." The reason behind the refusal to initiate a preliminary ruling procedure, thus, lies in the fact that the Czech Constitutional Court considers the EU law to represent sub-constitutional law which is not to be interpreted and applied by the Constitutional Court itself, but by ordinary courts. ${ }^{20}$ For this reason, these courts are obliged to refer questions for a preliminary ruling, whereas the Constitutional Court does not, since it is not concerned with the EU law.

However, this approach may not be correct as it is based on the assumption that the necessary prerequisite (of a duty) to initiate a preliminary ruling procedure pursuant to Art. 267 TFEU is the necessity not only to interpret the EU

19 Judgement of the Constitutional Court, II. ÚS 1009/08 - Pfizer, ECLI:CZ:US:2009:2. US.1009.08.2; see below, e.g.: STEHLÍK, Václav. The obligatory preliminary ruling procedure and its enforcement in the Czech and Slovak legal order. UWM Law Review. Olsztyn: University of Warmia and Mazury, n. 3, 2011, p. 6-25.

20 See further HAMULÁK, Ondrej. Flexibilita ústavního pořádku, právo Evropské unie a marginalia k Listině základních práv Evropské unie (Flexibility of constitutional order, EU law and marginality to the EU Charter of Fundamental Rights). In Mlsna, P. (ed.). Ustava $\check{C} R$ - vznik, vývoj a perspektivy. Praha: Leges, 2011, pp. 288-308. 
law, but also to apply it subsequently in the national court proceedings where the question for a preliminary ruling originated from. We acknowledge that this is true in a majority of cases. Nevertheless, there are cases where it is necessary to establish the correct interpretation of the EU law so that the national court be able to interpret national law in the light of the EU law. This may be true also in case of the Constitution, or to be able to assess the compliance of an implementing national provision with the constitution ${ }^{21}$ in particular in case of directives, ${ }^{22}$ or if it is necessary to ascertain whether the constitutional law allows a certain transfer of power to the EU. ${ }^{23}$

Thus, the initiation of the preliminary ruling procedure might be necessary in cases of individual constitutional complaints, in case of an abstract control of legality as well as in cases of a concrete control of legality. In all these cases it might be needed to establish whether the state or its bodies have acted within the margin of discretion left by the EU law and are, therefore, still bound by the constitutional law, or whether the EU act is ultra vires and must not be applied. Finally, yet importantly, it might be necessary for the Constitutional Court to interpret the EU law in order to be able to evaluate its compatibility with the material core of the Constitution. ${ }^{24}$

There is no doubt that the Czech Constitutional Court carries out all the aforementioned tasks. ${ }^{25}$ Indeed, in the above-cited Cukerné kvóty (Sugar Quotas) decision, the Constitutional Court already concluded that it would "examine the legal key to distribution of production quotas in terms of national constitutional law interpreted in the light of Community law."26 Similarly, in a different decision, the Constitutional Court concluded that "if there are several interpretations of the Constitution, including the Charter of Fundamental Rights and Free-

21 This is true only in those cases where the Czech legislator had a margin of discretion. BOBEK, Michal., KOMÁREK, Jan., PASSER, M., Jan, GILLIS, M. Předběžná otázka v komunitárním právu. Praha: LINDE Praha a.s., 2005, p. 71.

22 Constitutional court is in such a case obliged to initiate the preliminary ruling procedure and decide the case only after the judgment of the Court of Justice has been delivered. Otherwise, the uniform application of the EU law is at stake. See MALENOVSKÝ, Jiř́, Ambivalentní komunikace a spolupráce Soudního dvora EU a ústavních soudů jejích členských států in Vlastimil Göttinger (ed.) Book of proceedings from international conference EUROPEAN CONSTITUTIONALISM IN THE CONTEXT OF JUDICIAL DIALOGUE, Ústavní soud: Brno, 2016, p. 67.

23 LOHSE, E., Julia, The German Constitutional Court and Preliminary References - Still a Match not Made in Heaven? German Law Journal. vol. 16, issue 6, 2015, p. 1495.

24 Ibidem.

25 Similarly, to the German Constitution Court who had been using the very same rhetoric. However, the later has already referred for the preliminary ruling.

26 This effect of EU law on national law is in judgments of the Constitutional court referred to as the "prozařováni" and closely resembles the German Drittwirkung. See also ZEMÁNEK, Jiř́i. České ústavní soudnictví v evropském ústavním prostoru in Vlastimil Göttinger (ed.) Book of proceedings from international conference EUROPEAN CONSTITUTIONALISM IN THE CONTEXT OF JUDICIAL DIALOGUE, Ústavní soud: Brno, 2016, p. 91. 
doms as its integral part, and only some of them lead to fulfilling the obligations assumed by the Czech Republic in connection with its membership in the EU, an interpretation conducive to the fulfilment of that obligation must be selected over an interpretation that prevents it. ${ }^{37}$ Thus, in neither of these cases the EU law was to be applied, but the Constitutional Court undoubtedly had to interpret it as this was a prerequisite for the subsequent interpretation and application of the Czech law. ${ }^{28}$ In terms of the sense and purpose of Art. 267 TFEU, referring a question for a preliminary ruling in these situations would make sense provided that there are doubts about how to interpret the EU law correctly.

In the Pfizer judgment, the Czech Constitutional Court emphasised (probably to avoid the conclusion that it had a duty to refer a question for a preliminary ruling) the distinctive nature of the proceedings that can be conducted before it based on an individual's initiative. This would be of little interest if the Constitutional Court had not also noted that "distinguishing between the roles of ordinary and administrative courts, on the one hand, and the Constitutional Court, on the other hand, is fully within the competence of national legislature. Under the relevant provisions of the EC Treaty and the Treaty on European Union, as well as the ECJ case law, the competence to establish the system of procedural rules is, in principle, vested with the Member States." There, the Constitutional Court cited the Unibet $t^{29}$ case, but seemingly it did so rather incorrectly. This is because the principle of procedural autonomy concerns national procedural rules and, therefore, cannot be automatically applied to EU procedural rules. ${ }^{30}$ In other words, it is not meant to and cannot limit a procedural duty stipulated by autonomous law (EU law) which concerns an autonomously defined entity (a court pursuant to Art. 267 TFEU). ${ }^{31}$ Thus, the Constitutional Court could perhaps examine whether or not it was the court of last instance, but it should not have concluded that it was unaffected by Art. 267 TFEU for reasons based solely in national law.

27 Pl.ÚS 66/04 Evropský zatýkací rozkaz, ECLI:CZ:US:2006:Pl.US.66.04.

28 See also HAMULÁK, Ondrej; KERIKMÄE, Tanel. Indirect Effect of EU Law under Constitutional Scrutiny - the Overview of Approach of Czech Constitutional Court. International and Comparative Law Review, 2016, Vol. 16, No. 1, pp. 69-82.

29 C-432/05 Unibet (London) Ltd and Unibet (International) Ltd v Justitiekanslern, ECLI:EU:C:2007:163.

30 For detailed explanation see for example STEHLÍK, Václav. Aplikace národních procesních předpisů v kontextu práva Evropské unie. Prague: Leges 2012, p. 225 et seq.

31 The Court of justice clearly stated that "In the absence of Community rules on this subject, it is for the domestic legal system of each Member State to designate the courts having jurisdiction and to determine the procedural conditions governing actions at law intended to ensure the protection of the right which citizens have from the direct effect of Community law, it being understood that such conditions cannot be less favorable than those relating to similar actions of a domestic nature." See case C-33/76 Rewe-Zentralfinanz eG and Rewe-Zentral AG v Landwirtschaftskammer für das Saarland. ECLI:EU:C:1976:188. 
3.3 Case 'Československá obchodní banka': Constitutional Court does not Authoritatively Interpret the EU Law Argument

The approach of the Constitutional Court outlined above, according to which this Court is not a "court" within the meaning of Art. 267 TFEU, has also been adopted by the supreme courts of the Czech Republic. In proceedings in case File No. 30 Cdo 3378/2018, ${ }^{32}$ the Supreme Court dealt with a complaint raised by an individual seeking compensation for damage allegedly caused by the Constitutional Court on the grounds of a violation of the EU law. The nature of the alleged violation was that the Constitutional Court had not referred a question concerning the interpretation of secondary EU law to the Court of Justice for a preliminary ruling. In its decision, the Supreme Court first recalled the Vaassen-Göbbels ${ }^{33}$ decision, noting that the Constitutional Court met the criteria set by the Court of Justice, and concluded that the Constitutional Court was able to refer questions for a preliminary ruling. However, it also noted that the Constitutional Court could only do this based on its own discretion, i.e., it had no duty to do so. According to the Supreme Court, the reason in the light of Constitutional Court's case law consists in the fact that it does not apply the EU law, nor does it provide a binding interpretation thereof. Thereby, the Supreme Court fully adopted the Constitutional Court's conclusions without subjecting them to a critical analysis.

It did so despite the fact that the Constitutional Court, too, interprets the EU law, which is explicitly accepted in a decision preceding the Supreme Court's judgment, specifically in a 2018 decision concerning the case Československá obchodní banka, ${ }^{34}$ examined by the Constitutional Court. ${ }^{50}$ This case concerned a constitutional complaint against the decision of the Supreme Court, which according to the complainant - should have, given the circumstances of the case, initiated a preliminary ruling procedure. In the case, the Constitutional Court primarily addressed the duty of last instance courts to initiate a preliminary ruling procedure, the application of the CILFIT criteria, and the acte clair doctrine. There, it noted that as part of a review of proper application of this doctrine, it could be compelled to carry out a relatively "detailed review of the application and interpretation of EU law." It further noted that "[t]he Constitutional Court's aim in these cases is not, however, to look for the correct application of the EU law or even to interfere with the competence of the Court of Justice by authoritatively interpreting the contents of the EU law, since the Constitutional Court examines exclusively whether the application of the EU law by common courts was arbitrary or unsustainable." That assertion is clearly true in all its parts but it does not explain why the Constitutional Court should be excluded from the duty to refer a question for a preliminary ruling. In such a case, the reference criterion is the

3230 Cdo 3378/2018, ECLI:CZ:NS:2018:30.CDO.58.2018.1.

33 C-61/65 G. Vaassen-Göbbels (a widow) v Management of the Beambtenfonds voor het Mijnbedrijf. ECLI:EU:C:1966:39.

34 II. ÚS 3432/17 - Československá obchodní banka, ECLI:CZ:US:2018:2.US.3432.17.1. 
Constitution, which, however, should be interpreted in a manner corresponding to the EU law and interpretation of the EU law by the Court of Justice. ${ }^{35}$ This means, in fact, that in terms of the EU law (rather than national law), the Court acts as an ordinary court and, thus, rather as a court according to Article 267 TFEU. ${ }^{36}$

\section{Consequences of the Unwillingness of the Constitutional Court to Refer Questions for a Preliminary Ruling and Judicial Dialogue}

The considerations described above clearly indicate political, rather than a strictlylegal motivation on the part of the Constitutional Court not to refer questions for a preliminary ruling. This makes sense because, in a multipolar judicial system lacking a clear hierarchy of institutional relations between national and EU courts, the preliminary ruling procedure imposes such a hierarchy through the introduction of a binding and authoritative interpretation of the EU law. ${ }^{37}$ Moreover, the Court of Justice often anticipates the interpretation of national law to an extent that does not correspond to its competences in the preliminary ruling procedure. Not referring a question for a preliminary ruling is, thus, a way to avoid a direct conflict in situation where the legal opinion of the Constitutional Court would differ from that of the Court of Justice, or even the latter's opinion on the resolution of the case itself. ${ }^{38}$

In terms of legal theory, the Constitutional Court's approach means that an emphasis is placed on the internal perspective of the problem. In other words, Art. 267 TFEU and the term "court" is not approached on the basis of the interpretation of the term by the Court of Justice, but via the Czech law. However, the Court of Justice requires the external perspective, determined by the EU law. We suppose that the external approach is more appropriate as it better corresponds to the autonomous position of the EU law and its supranational nature. In contrast to what the Constitutional Court declares in its judgements, the EU law is not sub-constitutional - i.e. subordinate - law, but autonomous. It is a legal

35 See decision of the Constitutional Court of 16 January 2007, File No. Pl. ÚS 36/05. ECLI:CZ:US:2007:Pl.US.36.05.1. For analysis see STEHLÍK, Václav. Constitutional review and the preliminary ruling procedure: Commentary on the CCB decision of the Czech Constitutional Court. Czech Yearbook of International Law, 2019, pp. 117-129.

36 This is probably one of the reasons why the Constitutional Court avoids referring any matters for a preliminary ruling.

37 For an explanation of a concept of multipolarity of the judicial system in European Union see for example HAMULÁK, Ondrej. Právo Evropské unie v judikatuře Ústavního soudu České republiky: reflexe členství a otázek evropského práva v ústavní judikatuře. Prague: Leges, 2010, p. 86.

38 In this context, Malenovský speaks of a preventive control exercised by the courts of the Member States in order to prevent activist controversial solutions by the Court of Justice. MALENOVSKÝ, Jiří: 60 let Evropských společenství: od francouzského „supranacionálního“ smluvního projektu k jeho německému „podústavnímu“ provádění. Právník: Teoretický časopis pro otázky státu a práva, no. 7, 2012. p. 720. 
system in which the founding treaties act as a "parallel constitution", with which national law must comply. The constitutional law is no exception. ${ }^{39}$

Moreover, the isolationist approach of the Czech Constitutional Court does not always bring the intended results and is unable to prevent excesses. An example of such an excess could be the seen in case Holubec. ${ }^{40}$ Neither in this nor in other similar cases did the Constitutional Court refer a question for a preliminary ruling; this was only done later by the Supreme Administrative Court. The Court of Justice's preliminary ruling on the questions raised was also based on incomplete and inaccurate information on the Constitutional Court's case law. The Constitutional Court attempted to reconcile this shortcoming by means of an unofficial explanatory letter (amici curiae brief) sent to the Court of Justice. However, this was disregarded by the Court of Justice due to procedural rules. Had the Constitutional Court itself referred the relevant question for a preliminary ruling, it would have been able to explain its opinion to the Court of Justice directly.

If the preliminary ruling procedure were to be understood as an opportunity for a dialogue between courts, then not initiating such procedure means a voluntary abdication of the opportunity to communicate with and influence the other court. ${ }^{41}$ This has been long recognized and well understood by some of the European constitutional courts. ${ }^{42}$ Italien and German constitutional courts, who had been for a long time reluctant to initiate this procedure, later changed their approach in order to take the advantage of the possibility to directly affect the Court of Justice. It also should be noted that this strategy may not always be successful.

An example of a failed attempt to initiate a judicial dialog between the courts may be demonstrated by the case Gauweiler..$^{43}$ Not only the issue discussed in the

39 MALENOVSKÝ, Jiří. Protichůdné zájmy v řízení o předběžné otázce a jejich důsledky. Právní rozhledy, no. 6, 2019. p. 195.

40 Judgement of the Constitutional Court, Pl. ÚS 5/12 of 31 January 2012. See also HAMULÁK, Ondrej, The Unbearable Lightness of Being Guardian of the Constitution (Revolt and Revolution Dilemma in the Approach of Czech Constitutional Court Vis-àVis EU and Supranational Legal Order). European studies - The Review of European Law, Economics and Politics, vol. 1, pp. 103-112.

41 See also HAMULÁK, Ondrej. The Unbearable Lightness of Being Guardian of the Constitution (Revolt and Revolution Dilemma in the Approach of Czech Constitutional Court Vis-à-Vis EU and Supranational Legal Order). European studies - The Review of European Law, Economics and Politics. 2014, vol. 1, pp. 103-112.

42 Zemánek speaks of "open (cooperative) constitutionalism". Communication between courts is not perceived as a threat to sovereignty but rather a chance to provide for normative impulses. Courts are not competitors, but rather partners. See ZEMÁNEK, Jiří. České ústavní soudnictví v evropském ústavním prostoru in Vlastimil Göttinger (ed.) Book of proceedings from international conference EUROPEAN CONSTITUTIONALISM IN THE CONTEXT OF JUDICIAL DIALOGUE, Ústavní soud: Brno, 2016, p. 95.

43 C-62/14 Peter Gauweiler and other v. Deutscher Bundestag. ECLI:EU:C:2015:400. 
question but also the manner in which the German Federal Constitutional Court referred this question for a preliminary ruling was apparently not meant to start a serious dialogue but rather simply confirm the existing legal opinion of the German court. ${ }^{44}$ The question was interesting be couse of the court attempted to narrow the room for the interpretation by the Court of Justice by including an exhaustive list of clarifying conditions. At the same time, the outcome of the procedure was essentially predetermined as the Federal Constitutional Court indicated the potential consequences of the decision in case the Court of Justice would have arrived at different than anticipated conclusions. We concur with the opinion expressed in literature that the Federal Constitutional Court went beyond the limits of a simple question and essentially tried to threaten and dictate the answer to the Court of Justice. ${ }^{45}$ We are not aware of any other question referred for a preliminary ruling where a national court would communicate with the Court of Justice in such an outspoken manner.

Another example of dysfunctional judicial dialogue and even of an open resistance against the Court of Justice is a decision of the Danish Supreme Court in the case File No. 15/2014. The Danish Supreme court first attempted to communicate with the Court of Justice by means of two preliminary questions. Their purpose was most likely to offer the Court of Justice a possibility to review its previous case law. The Court of Justice, however, very clearly and perhaps not too diplomatically answered that it is the Danish court who is expected to change its previous settled case law in order to comply with the EU law. ${ }^{46}$ As a result, Danish Supreme Court, who most likely awaited a different answer, avoided the judgment of the Court of Justice by relying on the Danish accession legislation in by its own decision. According to this national regulation the decision of the Court of Justice was ultra vires. ${ }^{47}$ It is hard to criticise such an approach from a theoretical perspective. The question, however, is what useful could such a decision bring. From a practical point of view, it only caused problems that will not

44 See MALENOVSKÝ, Jiří, Ambivalentní komunikace a spolupráce Soudního dvora EU a ústavních soudů jejích členských států in Vlastimil Göttinger (ed.) Book of proceedings from international conference EUROPEAN CONSTITUTIONALISM IN THE CONTEXT OF JUDICIAL DIALOGUE, Ústavní soud: Brno, 2016, p. 69.

45 See also CLAES, Monica. The Validity and Primacy of EU Law and the 'Cooperative Relationship' between National Constitutional Courts and the Court of Justice of the European Union. Maastricht Journal of European and Comparative Law. 2016, Vol. 23, Issue 1, p. 170, KELEMEN, R. Daniel. On the Unsustainability of Constitutional Pluralism European Supremacy and the Survival of the Eurozone. Maastricht Journal of European and Comparative Law. 2016, vol. 23, issue 1, p. 137 or HAMULÁK, Ondrej; KOPAL, David; KERIKMÄE, Tanel. Walking a Tightrope - Looking Back on Risky Position of German Federal Constitutional Court in OMT Preliminary Question. European Studies : the review of European law, economics and politics, 2016, vol. 3, pp. 115-141.

46 C-441/14. Dansk Industri (DI), acting on behalf of Ajos A/S v Estate of Karsten Eigil Rasmussen. ECLI:EU:C:2016:278.

47 Judgement of the Danish Supreme Court File No. 15/2014 of $6^{\text {th }}$ of December, 2016 (English translation) available at http://www.supremecourt.dk. 
be easy to solve. A change in the conceptual approach of the Court of Justice is not likely as is not also the change of the Danish accession legislation. ${ }^{48}$

The Italian Constitutional Court used the preliminary ruling procedure in a similar fashion (and successfully, unlike the German Federal Constitutional Court and Danish Supreme Court) in response to the judgment of the Court of Justice in Taricco I. ${ }^{49}$ The Court of Justice issued a preliminary ruling on a question referred to it by a common court in Italy concerning the possibility of punishment for an offence against the interests of the European Union, which was subject to limitation under Italian law. However, the decision of the Court of Justice in the interest of the European Union was not welcomed by the Italian Constitutional Court. It subsequently raised its own question in the case of Taricco $I I{ }^{50}$ where it explained its position based on the principles of the Italian constitutional law. This offered room for the Court of Justice to interpret its previous decision and to clarify it in relation to the Italian constitution. ${ }^{51}$

The Court of Justice responded in a reconciliatory and constructive manner. It clarified the interpretation of the EU law while simultaneously respecting national law in order to facilitate a functional judicial dialogue. This left Italian courts with enough room to enforce national rules, where the issue itself was to be ultimately resolved by the Italian legislator. The strategy chosen by the Italian Constitutional Court was successful because it enabled it to protect the values it considered important without giving rise to a direct conflict with the Court of Justice and the EU law. ${ }^{52}$

48 SEHNÁLEK, David. Specifika výkladu práva Evropské unie a jeho vnitrostátní důsledky. Prague: C.H.Beck, 2019, p. 47 et seq.

49 C-105/14 Criminal proceedings against Ivo Taricco and Others. ECLI:EU:C:2015:555.

50 C-42/17 Criminal proceedings against M.A.S. and M.B. ECLI:EU:C:2017:936.

51 The Italian Constitutional Court by forming its preliminary ruling request (resolution of 23 November 2016, n. 24/2017) with a strong and detailed argumentation based on fundamental rights which form a part of constitutional values, it forced the Court of Justice to review its approach in so called Taricco saga. The Court of Justice in its subsequent reply (C-42/17 M.A.S. a M.B., ECLI:EU:C:2017:936) mentioned its opinion in relation to the unconditionality of the EU law application (the obligation to efectively protect financial interests of the EU under art. 325 TFEU), which results from its previous case-law (C-105/14 Taricco a ostatní, ECLI:EU:C:2015:555) and admitted an exception based on the principle of protection of fundamental rights (particularly the principle of legality of criminal repression). See below, for instance: PICCIRILLI, Giovanni. The 'Taricco Saga': The Italian Constitutional Court continues its European journey: Italian Constitutional Court, Order of 23 November 2016 no. 24/2017; Judgment of 10 April 2018 no. 115/2018 ECJ 8 September 2015, Case C-105/14, Ivo Taricco and Others; 5 December 2017, Case C-42/17, M.A.S. and M.B. European Constitutional Law Review. Cambridge: Cambridge University Press, vol. 14, n. 4 2018, p. 814-833; or BUDINSKA, Barbora, VIKARSKA, Zuzana. Judicial dialogue after Taricco II: who has the last word, in the end? EU Law Analysis, 7. 12. 2017.

52 See also VIKARSKÁ, Zuzana. O daňových podvodníkoch a ústavnej identite (Taricco II) [online].

Available http://jinepravo.blogspot.com Accessed: 25.11.2019. 
It is true, however, that a subsequent decision of the Italian Constitutional Court did not maintain the reconciliatory spirit. ${ }^{53}$ The court made full use of the possibilities offered to it by the Court of Justice in Taricco II and expressly acknowledged its power to interpret the EU law. At the same time, however, it interpreted the relevant EU legislation in a manner that did not correspond to the conclusions of the Court of Justice. It must be stressed that this interpretation did not in fact result in a violation of the EU law since it did not affect the outcome of the case at hand. We may, thus, speculate that the primary aim of the Italian Constitutional Court was not to assert itself against the Court of Justice, but against other Italian courts. ${ }^{54}$

Therefore, if a constitutional court refuses to refer questions for a preliminary ruling, it gives up on a significant possibility to influence the case law of the Court of Justice (mutual fertilization). ${ }^{55}$ This is not always the best strategy, as shown e.g. in the outcome of the Holubec case where the Czech Constitutional Court explicitly denied the application of the EU law based on the interpretation of the Court of Justice as it found it ultra vires without even trying to give the Court of Justice a chance to get acquainted with its own legal opinion and, thus, without giving the Court of Justice a possibility to adapt the interpretation of the EU law to the specific Czech conditions of the case. From this perspective, the Italian counterpart was more successful.

On a more positive note, the existing case law of the Czech Constitutional Court does not preclude categorically the option of presenting questions for a preliminary ruling. A change of the Constitutional Court's approach might be possible and the words used by the Constitutional Court offer a certain hope in this regard. The Constitutional Court does not regard itself as a court under art. 267 TFEU in complains on the breach to the right for statutory judge as guaranteed by the Czech constitutional rules. ${ }^{56}$ In this regard it is up to ordinary courts to initiate a preliminary ruling procedure. However, the Constitutional Court made it clear that the refusal of its competence under art. 267 TFEU does not automatically apply to all other cases. Thus, we assume that a special case should be if the Constitutional Court would tend to decide on non-application of the EU legislation because of the interference with the material core of the Constitution. In such a situation, the Court should consider the assessment of

53 For English summary of the judgment see No 115/2018 see https://www.cortecostituzionale.it.

54 SEHNÁLEK, David. Specifika výkladu práva Evropské unie a jeho vnitrostátní důsledky. Prague: C.H.Beck, 2019, p. 48 or AMALFITANO, Chiara. Two Courts, two Languages? The Taricco Saga Ends on a Worrying Note. [online]. Available https://verfassungsblog.de/ Accessed: 25.11.2019.

55 ZEMÁNEK, Jiří. České ústavní soudnictví v evropském ústavním prostoru in Vlastimil Göttinger (ed.) Book of proceedings from international conference EUROPEAN CONSTITUTIONALISM IN THE CONTEXT OF JUDICIAL DIALOGUE, Ústavní soud: Brno, 2016, p. 95

56 Art. 26 para 1 and 38 para 1 of the Czech Charter. 
the authoritative interpretation of the act at issue which would be given by the Court of Justice.

\section{The Constitutional Court as a Promotor of Judicial Dialog between General Czech Courts and the Court of Justice}

A certain reluctance of the Constitutional Court to refer matters for a preliminary ruling is contrasted with its approach to the procedure in general. This is a reason why it would not be correct to interpret the above as evidence that the Czech Constitutional Court is Eurosceptic and unwilling to engage in a judicial dialogue with the Court of Justice. The Constitutional Court may not be inclined to communicate directly, but it does consider the preliminary ruling procedure an important part of Czech justice, to such a degree so that it has included it in the Czech constitutional framework.

In the above-cited decision in Pfizer case, it indicated its interest that ordinary courts refer matters for a preliminary ruling. ${ }^{57}$ The Constitutional Court noted that while referral of a question for a preliminary ruling is a matter of the EU law, a failure to do so might constitute violation of the constitutionally guaranteed right to a statutory judge. According to the Constitutional Court, the right to a statutory judge is violated "if a Czech court (whose decision is not subject to other remedies set out in sub-constitutional law) fails to refer a matter for a preliminary ruling arbitrarily, i.e. in violation of the principle of the rule of law (Article 1 (1) of the Constitution of the Czech Republic). The Constitutional Court states that it also considers an arbitrary conduct a case where a court of last resort which applies the rules of Community law fails to consider whether or not it would be appropriate to refer the matter to the ECJ for a preliminary ruling and fails to provide proper justification for the omission, including assessment of the exceptions established by the ECJ in its case law."

The Constitutional Court has accepted and respects the exceptions established by the Court of Justice in the CILFIT decision, but applies them with certain modifications. Pursuant to the decision of the Constitutional Court the right to a statutory judge is not violated if none of the parties sought to refer the matter for a preliminary ruling. ${ }^{58}$ The Constitutional Court believes this constitutes a situation covered by the acte clair doctrine. However, a question remains as to whether doubts about interpretation should be linked to the procedural activities of the parties. We suppose that this is not correct. Firstly, it is the court itself who has to be certain about interpretation.

Furthermore, in the above-cited Československá obchodní banka judgment, the Constitutional Court responded to a situation where the EU law was inter-

57 MALENOVSKÝ, Jiří. Protichůdné zájmy v řízení o př̀edběžné otázce a jejich důsledky. Právní rozhledy, no. 6, 2019. p. 195.

58 II. ÚS 1248/13 ECLI:CZ:US:2014:2.US.1248.13.1. 
preted differently at different judicial instances. It resolved the situation pursuant to the judgment of the Court of Justice in Ferreira da Silva, ${ }^{59}$, i.e. concluded that a difference in interpretation does not automatically create a duty to refer a question for a preliminary ruling. However, the headnote does not follow the intention set out in Ferreira da Silva. This is because the Constitutional Court noted that "[i]f a common court against whose decision there are no remedies has no reasonable doubts about the interpretation of a provision of EU law, it is not required to refer the matter for a preliminary ruling to the Court of Justice of the European Union, not even if the asserted interpretation of EU law differs from the interpretation of lower courts in the same case." The Constitutional Court, thus, established the non-referral for a preliminary ruling in such cases as a general rule. This is contrary to an opinion of the Court of Justice that established that the general rule is to refer such matters for a preliminary ruling.

In the same judgment, the Constitutional Court further inferred that the duty to refer a matter for a preliminary ruling does not arise in cases that are unique and have no generalised implications for the EU law. This was based on the opinion of Advocate General Francis Jacobs of 10 July 1997 in case Wiener. ${ }^{60}$ However, we believe that the case law of the Court of Justice, especially in CILFIT, does not directly and clearly support such a conclusion. While it is true that the sense and purpose of the preliminary ruling procedure is to prevent differences in interpretation of the EU law in the Member States, its other purpose is also to ensure correct interpretation. This is important in all cases, no matter how unique they could be.

The approach of the Czech Constitutional Court is paradoxical especially in terms of its consequences. Despite the above-outlined problematic exception, the Constitutional Court tries to encourage courts to refer questions for a preliminary ruling based on the Czech Charter of Fundamental Rights and constitutional law in general. There, however, lies the problem as this approach does not take into account the autonomous nature of the EU law and its primacy over the national law, including constitutional law. The Constitutional Court measures the correctness of interpretation of the EU law from the perspective of the Czech constitutional order. The nature of the EU law, however, is better served by a different approach. The measure of correctness of interpretation of national law should always be based on Art. 267 TFEU. ${ }^{61}$ In terms of the EU law, this approach poses a certain risk of inconsistent application of Art. 267 TFEU in different Member States, depending on the scope of human rights protection established by national constitutional law. ${ }^{62}$ This is not desirable. It is further

59 C-160/14 Ferreira da Silva e Brito and Others, ECLI:EU:C:2015:565.

60 C-338/95 Wiener S.I. GmbH v Hauptzollamt Emmerich, ECLI:EU:C:1997:352, paragraph 50.

61 MALENOVSKÝ, Jiří. Protichůdné zájmy v řízení o předběžné otázce a jejich důsledky. Právní rozhledy, n. 6, 2019. p. 194.

62 See MALENOVSKÝ, Jiř́, Ambivalentní komunikace a spolupráce Soudního dvora EU a ústavních soudů jejích členských států in Vlastimil Göttinger (ed.) Book of proceedings 
a matter of argument whether such an active approach is actually necessary in a situation where the EU law does have mechanisms to control proper application of Art. 267 TFEU. It is true, however, that none of these mechanisms gives individuals the right to a review their case on its merits, which the Constitutional Court's approach does.

\section{Conclusions and Closing Remarks}

In the introductory part of this article, three possible relations between the Constitutional Court on one side and EU law and preliminary ruling procedure on the other side were outlined. It is apparent that the Czech Constitutional Court has decided to base its approach on the traditional perception of the relation between the domestic and international law. This means, that ideas of European constitutionalism as well as the federalist approach towards the EU law were rejected by this court.

It is true that the Constitutional Court recognizes specific nature of the EU law and accepts the fact that it is another system of law, this acceptance is, however, not unconditional as it should be according to the settled case law of the Court of Justice. From this perspective, both the EU law and the Czech law as form new functional system composed of two separate systems of law in which they interact with a potential of conflicts. The role of the Constitutional Court might be to resolve them, but only exceptionally, as was for example the case Holubec.

According to the Constitutional Court the EU law does not form a part of the Czech constitutional order. Consequently, the Constitutional Court does not seem to be bound by it as the EU law stands outside its decision-making framework. As a result, the Constitutional Court does not consider itself to be a court according to Art. 267 TFEU. This approach results, however, in the absence of a direct participation of the Constitutional Court in a dialog with the European judiciary.

The truth is that decisions of the Constitutional Court are held in a spirit of cooperative monolog with the Court of Justice and the EU law. Nevertheless, such an approach can hardly result in a possibility to influence the Court of Justice and to contribute to the development of the EU law and European integration.

\section{References}

AMALFITANO, Chiara. Two Courts, two Languages? The Taricco Saga Ends on a Worrying Note. [online]. Available https://verfassungsblog.de/ Accessed: 25.11.2019.

from international conference EUROPEAN CONSTITUTIONALISM IN THE CONTEXT OF JUDICIAL DIALOGUE, Ústavní soud: Brno, 2016, p. 71. 
BOBEK, Michal., KOMÁREK, Jan., PASSER, M., Jan, GILLIS, M. Předběžná otázka v komunitárním právu. Praha: LINDE Praha, 2005.

BUDINSKA, Barbora, VIKARSKA, Zuzana. Judicial dialogue after Taricco II: who has the last word, in the end? EU Law Analysis, 7. 12. 2017.

CLAES, Monica. The Validity and Primacy of EU Law and the 'Cooperative Relationship' between National Constitutional Courts and the Court of Justice of the European Union. Maastricht Journal of European and Comparative Law. 2016, vol. 23, no. 1, p. 170, pp. 151-170.

GEORGIEV, Jiří. The Constitutional Review of the OMT Programme - The German Case. In: ŠIŠKOVÁ, Naděžda. The European Union - What is Next? Wolters Kluwer: Köln, 2018, p.165 et seq.

HAMULÁK, Ondrej, KOPAL, David, KERIKMÄE, Tanel. Walking a Tightrope - Looking Back on Risky Position of German Federal Constitutional Court in OMT Preliminary Question. European Studies: the review of European law, economics and politics, 2016, vol. 3, pp. 115-141.

HAMULÁK, Ondrej, Lessons from the "Constitutional Mythology" or How to Reconcile the Concepts of State Sovereignty with European Integration. DANUBE: Law and Economics Review, vol. 6, no. 2, pp. 75-90.

HAMULÁK, Ondrej, The Unbearable Lightness of Being Guardian of the Constitution (Revolt and Revolution Dilemma in the Approach of Czech Constitutional Court Visà-Vis EU and Supranational Legal Order). European studies - The Review of European Law, Economics and Politics, vol. 1, pp. 103-112.

HAMULÁK, Ondrej. Flexibilita ústavního pořádku, právo Evropské unie a marginalia $\mathrm{k}$ Listině základních práv Evropské unie (Flexibility of constitutional order, EU law and marginality to the EU Charter of Fundamental Rights). In Mlsna, P. (ed.). Ustava ČR - vznik, vývoj a perspektivy. Praha: Leges, 2011, pp. 288-308.

HAMULÁK, Ondrej. Právo Evropské unie v judikatuře Ústavního soudu České republiky: reflexe členství a otázek evropského práva v ústavní judikatuře. Prague: Leges, 2010.

HAMULÁK, Ondrej. The Czech Constitutional Court and the Question of an Active Use of the Preliminary Ruling Procedure. In R. Somssich (ed.) Central and Eastern European Countries after and before the Accession, Volume 2. Budapest: ELTE, pp. 121-128.

HAMULÁK, Ondrej. The Unbearable Lightness of Being Guardian of the Constitution (Revolt and Revolution Dilemma in the Approach of Czech Constitutional Court Visà-Vis EU and Supranational Legal Order). European studies - The Review of European Law, Economics and Politics. 2014, vol. 1, pp. 103-112.

HAMULÁK, Ondrej; KERIKMÄE, Tanel. Indirect Effect of EU Law under Constitutional Scrutiny - the Overview of Approach of Czech Constitutional Court. International and Comparative Law Review, 2016, Vol. 16, No. 1, pp. 69-82.

HAMULÁK, Ondrej; SULYOK, Márton, KISS, Lilla, Nóra. Measuring the 'EU'clidean Distance between EU Law and the Hungarian Constitutional Court - Focusing on the Position of the EU Charter of Fundamental Rights. Czech Yearbook of Public and Private International Law, 2019, vol. 10, pp. 130-150.

KELEMEN, R. Daniel. On the Unsustainability of Constitutional Pluralism European Supremacy and the Survival of the Eurozone. Maastricht Journal of European and Comparative Law. 2016, vol. 23, issue 1, pp. 136-150.

KUSTRA, Aleksandra. The first preliminary questions to the Court of Justice of the European Union referred by Italian Corte Costituzionale, Spanish Tribunal Constitucional, and French Conseil Constitutionnel. Comparative Law Review, Toruń: Faculty of 
Law, Mikulas Kopernik University, vol. 16, 2013, p. 159-182.

LOHSE, E., Julia, The German Constitutional Court and Preliminary References - Still a Match not Made in Heaven? German Law Journal. vol. 16, issue 6, 2015.

MALENOVSKÝ, Jiří, Ambivalentní komunikace a spolupráce Soudního dvora EU a ústavních soudů jejích členských států in GÖTTINGER Vlastimil (ed.) Book of proceedings from international conference EUROPEAN CONSTITUTIONALISM IN THE CONTEXT OF JUDICIAL DIALOGUE, Brno: Ústavní soud, 2016, pp. 66-73.

MALENOVSKÝ, Jiří. Protichůdné zájmy v řízení o předběžné otázce a jejich důsledky. Právní rozhledy, 2019, no. 6, pp. 191-197.

MALENOVSKÝ, Jiří: 60 let Evropských společenství: od francouzského „supranacionálního“ smluvního projektu k jeho německému „podústavnímu“ provádění. Právník: Teoretický časopis pro otázky státu a práva, 2012, vol. 151, no. 7, pp. 673-722.

NAVRÁTILOVÁ, Markéta. The preliminary ruling before the constitutional courts, In TÝČ Vladimír (ed.): International and European Dimension of Law Applied by Institutions of Member States, Brno: Masaryk University: 2008, pp. 695-705

PICCIRILLI, Giovanni. The 'Taricco Saga': The Italian Constitutional Court continues its European journey: Italian Constitutional Court, Order of 23 November 2016 no. 24/2017; Judgment of 10 April 2018 no. 115/2018 ECJ 8 September 2015, Case C-105/14, Ivo Taricco and Others; 5 December 2017, Case C-42/17, M.A.S. and M.B. European Constitutional Law Review, 2018, vol. 14, n. 4., pp. 814-833.

SCHEU, Harald, Christian. Koncepce komunitárního práva v praxi Evropského soudního dvora a v právní teorii. Mezinárodní vztahy, 2002, no. 1, p. 15-19.

SEHNÁLEK, David. Specifika výkladu práva Evropské unie a jeho vnitrostátní důsledky. Prague: C.H.Beck, 2019.

STEHLÍK, V., SEHNÁLEK, David, The Use of the Preliminary Ruling Procedure by Czech Courts: Historical Retrospective and Beyond, Baltic Journal of European Studies, no. 4, 2019.

STEHLÍK, Václav. Aplikace národních procesnich předpisů v kontextu práva Evropské unie. Prague: Leges, 2012.

STEHLÍK, Václav. Constitutional review and the preliminary ruling procedure: Commentary on the CCB decision of the Czech Constitutional Court. Czech Yearbook of International Law, 2019, pp. 117-129.

STEHLÍK, Václav. Ohlédnutí se (nejen) za řízením o předběžné otázce v prvních 15 letech členství České republiky v Evropské unii In KYSELOVSKÁ, Tereza et al. (eds.) In varietate concordia: soubor vědeckých statí k poctě prof. Vladimíra Týče. Brno: Masaryk University, pp. 347-366.

STEHLÍK, Václav. The obligatory preliminary ruling procedure and its enforcement in the Czech and Slovak legal order. UWM Law Review. Olsztyn: University of Warmia and Mazury, n. 3, 2011, pp. 6-25.

VIKARSKÁ, Zuzana. O daňových podvodníkoch a ústavnej identite (Taricco II) [online]. Available http://jinepravo.blogspot.com Accessed: 25.11.2019.

ZEMÁNEK, Jiří. České ústavní soudnictví v evropském ústavním prostoru in Vlastimil Göttinger (ed.) Book of proceedings from international conference EUROPEAN CONSTITUTIONALISM IN THE CONTEXT OF JUDICIAL DIALOGUE. Brno: Ústavní soud, 2016, p. 88-99. 